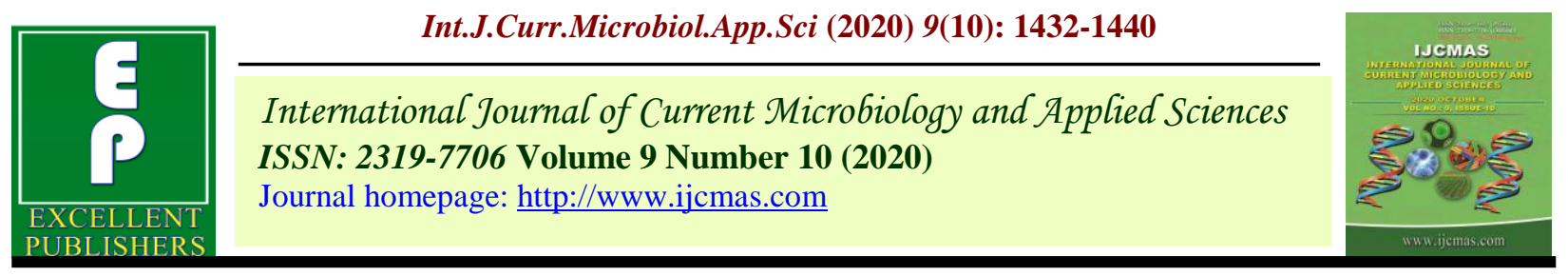

Original Research Article

https://doi.org/10.20546/ijcmas.2020.910.170

\title{
A Study for Entrepreneurial Knowledge of Rural Women on Stitching and Embroidery Products
}

\author{
Deepika Tiwari" and S. K. Sharma \\ ${ }^{1}$ SKRAU, Bikaner, India \\ ${ }^{2}$ Director Extension Education, SKRAU, BIKANER, Rajasthan \\ *Corresponding author
}

\section{A B S T R A C T}

\begin{tabular}{l|} 
Key w or d s \\
Skill gap, \\
Embroidery, \\
Stitching, \\
Knowledge, Skill \\
\hline Article Info \\
\hline $\begin{array}{l}\text { Accepted: } \\
12 \text { September } 2020 \\
\text { Available Online: } \\
10 \text { October } 2020\end{array}$ \\
\hline
\end{tabular}

Year after year, there has been marvelous change in the condition and the situations of the
women in India in specific community. The imparity of the sexes is an essential law in our
constitution. The changing position of women is not only indicating a signal of progress
but it also holds again the position of Indian women which was in Vedic period. Within
rural civilization, women have always been functioning in the field and dairy fields, but
their work was not remarkable. The contribution of women provides to complete basic
needs of house and also improved the dietary condition in society. When machine was
introduced in work place, then it led the great change in women's status. Women were
employed in factories. In $1901,6,38,000$ women worked in factories, mines and
plantations, forming 14.5 percent of the whole working force. There was incredible boost
in the employment of women who were engaged in secretarial or administrative capacities.
This paper comprises the identification of product in which rural women are most
interested. The paper also examines the entrepreneurial knowledge on selected products
and will be measuring the skill gap.

\section{Introduction}

In India Women entrepreneurship got popularity during 1970s. Today most of the women are coming forth to become entrepreneurs in different kinds of economic activities. Many women become professionals after their education with lot of hopes and dreams. Data of 1971 Census stated that the total female working population was 14.8 per cent of the total work force. The statistics shows that merely five per cent of the female population was in regular employment while 95 per cent were self-employed. Selfemployed women comprised mostly from rural areas. These women are illiterate and poor. Many women had education in highly advanced technology and skills. In India, during the last three decades, a large number of schemes and policies were introduced to develop and encourage women entrepreneurs. The national perspective plan for women stated the information that 94 per cent of female working forces were in unorganized sectors and 83 per cent of women has been involved in crop growing and associated activities like dairy, animal husbandry, sericulture, handicrafts, handlooms and forestry. During 1990s they became competent, capable, assertive and confident 
.They gained knowledge about different ventures and became confident in taking them. They were not limited up to small enterprise but extended their limits up to large scale industries. They became financially independent which further helped them in gaining confidence and living a successful better life.

Women of 21st century are becoming specialized in different fields especially in telecom and IT. With the impact of growing industrialization, their status has been distorted by means of the expansion of culture and knowledge of business. Women started entering in a range of higher levels of activities like electronics, manufacturing and medical. Today many new firms or industries are running ahead under the leadership of women.

\section{Materials and Methods}

\section{Research design}

The present study is Descriptive in nature as it accomplishes to analyze the position of rural women

Area of Study- Bikaner district of Rajasthan

Source of data- Primary data

The main objectives of this study include to identify the product out of stitching and embroidery for study purpose.

To measure the knowledge level and skill gaps in selected products of stitching and embroidery (Table 1).

Objective 1: To identify the product out of stitching and embroidery for study purpose

For the selection of product, ten products related to stitching and embroidery were selected on the basis of judgment of NGO trainers and interactions with field workers. The products were given to the respondents and their interest to learn the product was asked. As per the respondent's preference, the training of most preferred product was imparted to rural women. Five point rating scale was used to identify the preference of product. After ratings of each product by respondents, average of each product's rating was computed to find the extremely interested product for training.

\section{Selection of stitching product in Pemasar Village}

Data in the table 2 indicates that pent shirt product was given lowest rating and the average of this product was 1.76 followed by lehnga choli, frock, blouse and the average were $2.43,2.63$ and 3.93 respectively. Salwar kameez had highest average i.e. 4.23. So, the product selected for training was Salwar kameez.

\section{Selection of stitching product in Gusaisar Village}

Data in the table 3 indicates that Lehnga Choli product was given lowest rating and the average of this product was 2.26 followed by frock, pent shirt, and blouse having the average 2.36, 2.83 and 3.53 respectively. Salwar kameez has highest average i.e. 4. So, the product selected for training was Salwar kameez.

\section{Selection of stitching product in Seruna Village}

Data in the table 4 indicates that frock product was given lowest rating and the average of this product was 1.66 followed by pent shirt, salwar kameez, lehnga choli with the average 2.76, 2.93 and 3.00 respectively. Blouse had the highest average i.e. 4.23. So the product selected for training was Blouse. 
Selection of type of embroidery in Pemasar village

Data in the table 5 indicates that Kantha was given lowest rating and the average of this product was 2.3 followed by Phulkari, aari, kashidakari with average 2.76, 2.96 and 3.36 respectively. Chikankari had highest average i.e. 3.66. So the product selected for training was Chikankari.

\section{Selection of type of embroidery in Gusaisar Village}

Data in the table 6 indicates that phulkari was given lowest rating and the average of this product was1.73 followed by kantha, chikankari, aari with the average $2.73,3.13$ and 3.43 respectively. Kashidakari had highest average i.e. 3.96. So the product selected for training was Kashidakari.

\section{Selection of type of embroidery in Seruna} Village

Data in the table 7 indicates that Kantha was given lowest rating and the average of this product was 1.76, followed by phulkari, kashidakari, aari with the average 2.66, 3.26 and 3.3 respectively. Chikankari had highest average i.e. 3.6. So the product selected for training was Chikankari.

Objective 2: Measurement of the knowledge and skill of respondents in selected products of stitching and embroidery

For measuring the knowledge and skill of rural women, knowledge test and skill index was made. On the basis of scores, mean and standard deviation was computed and divided into three main categories. Level of knowledge and skill was analyzed on the basis of following categories:
Low

Medium

High

In the present investigation, it was decided to develop a complete package for embroidery and stitching trade for the rural women. Accordingly, training was designed in all the selected villages on the identified products of embroidery and stitching. Before imparting the training, the knowledge of the respondents as well as the skill about the particular product of stitching and embroidery were measured and later on the skill and knowledge about the same product were measured after imparting the training to respondents for the same products by applying the same schedule in order to measure the effectiveness of training.

The knowledge and the skill measured before the training have been presented in following paragraphs:

Knowledge level before training regarding stitching and embroidery in Pemasar Village

Data in the table 8 indicates that 33 per cent respondents had low level of knowledge regarding stitching and embroidery. Fifty per cent respondents had medium knowledge and 17 per cent respondents had high level of knowledge

Skill Level before training regarding stitching and embroidery in Pemasar Village

Data in the table 9 indicates that 20 per cent respondents had low level of skill regarding stitching and embroidery, 67 per cent respondents had medium level of skill and 13 per cent respondents had high level of skill 
Table.1 Sampling Technique and Sample Size

\begin{tabular}{|l|l|l|l|l|l|l|l|}
\hline Respondents & Seruna & Gusaisar & \multicolumn{2}{l|}{ Pemasar } & Total \\
\hline & $\begin{array}{l}\text { Total } \\
\text { Women }\end{array}$ & $\begin{array}{l}\text { Selected } \\
\text { respondents }\end{array}$ & $\begin{array}{l}\text { Total } \\
\text { Women }\end{array}$ & $\begin{array}{l}\text { Selected } \\
\text { respondents }\end{array}$ & $\begin{array}{l}\text { Total } \\
\text { Women }\end{array}$ & $\begin{array}{l}\text { Selected } \\
\text { respondents }\end{array}$ & \\
\hline Rural women & 125 & 30 & 144 & 30 & 150 & 30 & 90 \\
\hline Leaders in Villages & & 10 & & 10 & & 10 & 30 \\
\hline NGO Workers & & & & & & & 10 \\
\hline Total & & & & & & 130 \\
\hline
\end{tabular}

Table.2 Distribution of products according to their ratings in village Pemasar

\begin{tabular}{|c|l|c|}
\hline S.No. & \multicolumn{1}{|c|}{ Product } & Average \\
\hline 1. & Salwar Kameez & 4.23 \\
\hline 2. & Blouse & 3.93 \\
\hline 3. & Frock & 2.63 \\
\hline 4. & Lehnga Choli & 2.43 \\
\hline 5. & Pent Shirt & 1.76 \\
\hline
\end{tabular}

Table.3 Distribution of products according to their ratings in village Gusaisar

\begin{tabular}{|c|l|c|}
\hline S.No. & \multicolumn{1}{|c|}{ Product } & Average \\
\hline 1. & Salwar Kameez & 4.00 \\
\hline 2. & Blouse & 3.53 \\
\hline 3. & Pent Shirt & 2.83 \\
\hline 4. & Frock & 2.36 \\
\hline 5. & Lehnga choli & 2.26 \\
\hline
\end{tabular}

Table.4 Distribution of products according to their ratings in village Seruna

\begin{tabular}{|c|l|c|}
\hline S.No. & \multicolumn{1}{|c|}{ Product } & Average \\
\hline 1. & Blouse & 4.23 \\
\hline 2. & Lehnga Choli & 3.00 \\
\hline 3. & Salwar Kameez & 2.93 \\
\hline 4. & Pent Shirt & 2.76 \\
\hline 5. & Frock & 1.66 \\
\hline
\end{tabular}

Table.5 Distribution of products according to ratings given by respondents in Pemasar

\begin{tabular}{|c|l|c|}
\hline S.No. & \multicolumn{1}{|c|}{ Product } & Average \\
\hline 1. & Chikankari & 3.66 \\
\hline 2. & Kashidakari & 3.36 \\
\hline 3. & Aari & 2.96 \\
\hline 4. & Phulkari & 2.76 \\
\hline 5. & Kantha & 2.30 \\
\hline
\end{tabular}


Table.6 Distribution of products according to ratings given by respondents in Gusaisar

\begin{tabular}{|l|l|l|}
\hline S.No. & Product & Average \\
\hline 1. & Kashidakari & 3.96 \\
\hline 2. & Aari & 2.73 \\
\hline 3. & Chikankari & 3.13 \\
\hline 4. & Kantha & 2.73 \\
\hline 5. & Phulkari & 1.73 \\
\hline
\end{tabular}

Table.7 Distribution of products according to ratings given by respondents in Seruna

\begin{tabular}{|c|l|c|}
\hline S.No. & \multicolumn{1}{|c|}{ Product } & Average \\
\hline 1. & Chikankari & 3.6 \\
\hline 2. & Aari & 3.3 \\
\hline 3. & Kashidakari & 3.26 \\
\hline 4. & Phulkari & 2.66 \\
\hline 5. & Kantha & 1.76 \\
\hline
\end{tabular}

Table.8 Knowledge level before training in Pemasar village $(\mathrm{n}=30)$

\begin{tabular}{|c|l|l|c|c|}
\hline S.No. & \multicolumn{1}{|c|}{ Scores } & \multicolumn{1}{|c|}{ Category } & Frequency & Percentage \\
\hline $\mathbf{1 .}$ & Below 7 & Low & 10 & 33 \\
\hline 2. & $7-13$ & Medium & 15 & 50 \\
\hline 3. & Above 13 & High & 5 & 17 \\
\hline & Total & & 30 & 100 \\
\hline
\end{tabular}

Table.9 Skill level before training in Pemasar village $(n=30)$

\begin{tabular}{|c|l|l|c|c|}
\hline S.No. & \multicolumn{1}{|c|}{ Scores } & \multicolumn{1}{|c|}{ Category } & Frequency & Percentage \\
\hline $\mathbf{1 .}$ & Below 22 & Low & 6 & 20 \\
\hline $\mathbf{2 .}$ & $22-42$ & Medium & 20 & 67 \\
\hline $\mathbf{3 .}$ & Above 42 & High & 4 & 13 \\
\hline & Total & & 30 & 100 \\
\hline
\end{tabular}

Table.10 Knowledge level before training in Gusaisar village $(\mathrm{n}=30)$

\begin{tabular}{|r|l|l|c|c|}
\hline S.No. & Scores & Category & Frequency & Percentage \\
\hline $\mathbf{1 .}$ & Below 4 & Low & 6 & 20 \\
\hline $\mathbf{2 .}$ & $4-12$ & Medium & 21 & 70 \\
\hline $\mathbf{3 .}$ & Above 12 & High & 3 & 10 \\
\hline & Total & & 30 & 100 \\
\hline
\end{tabular}


Table.11 Skill level before training in Gusaisar village ( $\mathrm{n}=30)$

\begin{tabular}{|c|l|l|c|c|}
\hline S.No. & \multicolumn{1}{|c|}{ Scores } & Category & Frequency & Percentage \\
\hline $\mathbf{1 .}$ & Below 29 & Low & 6 & 20 \\
\hline $\mathbf{2 .}$ & $29-47$ & Medium & 19 & 63 \\
\hline $\mathbf{3 .}$ & Above 47 & High & 5 & 17 \\
\hline & Total & & 30 & 100 \\
\hline
\end{tabular}

Table.12 Knowledge level before training in Seruna village $(\mathrm{n}=30)$

\begin{tabular}{|c|l|l|c|c|}
\hline S.No. & \multicolumn{1}{|c|}{ Scores } & \multicolumn{1}{|c|}{ Category } & Frequency & Percentage \\
\hline $\mathbf{1 .}$ & Below 6 & Low & 4 & 13 \\
\hline $\mathbf{2 .}$ & 6-14 & Medium & 20 & 67 \\
\hline $\mathbf{3 .}$ & Above 14 & High & 6 & 20 \\
\hline & Total & & 30 & 100 \\
\hline
\end{tabular}

Table.13 Skill level before training in Seruna village $(\mathrm{n}=30)$

\begin{tabular}{|c|l|l|c|c|}
\hline S.No. & \multicolumn{1}{|c|}{ Scores } & \multicolumn{1}{|c|}{ Category } & Frequency & Percentage \\
\hline $\mathbf{1 .}$ & Below 22 & Low & 4 & 13 \\
\hline $\mathbf{2 .}$ & $22-48$ & Medium & 21 & 70 \\
\hline $\mathbf{3 .}$ & Above 48 & High & 5 & 17 \\
\hline & Total & & 30 & 100 \\
\hline
\end{tabular}

Fig.1

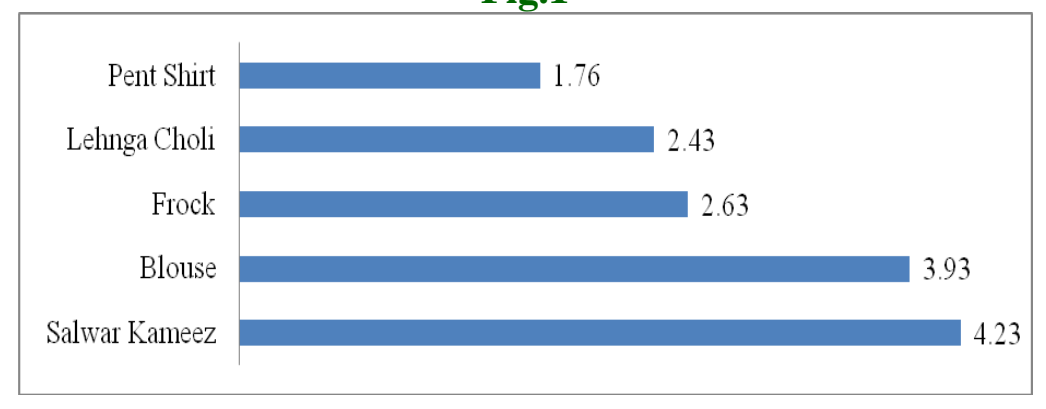

Fig.2 Distribution of products according to ratings given by respondents in Gusaisar

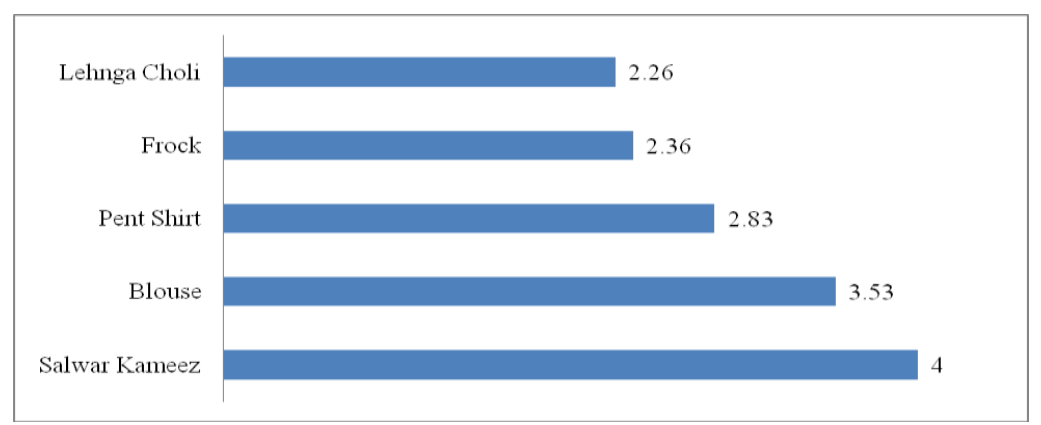


Fig.3 Distribution of products according to ratings given by respondents in Seruna

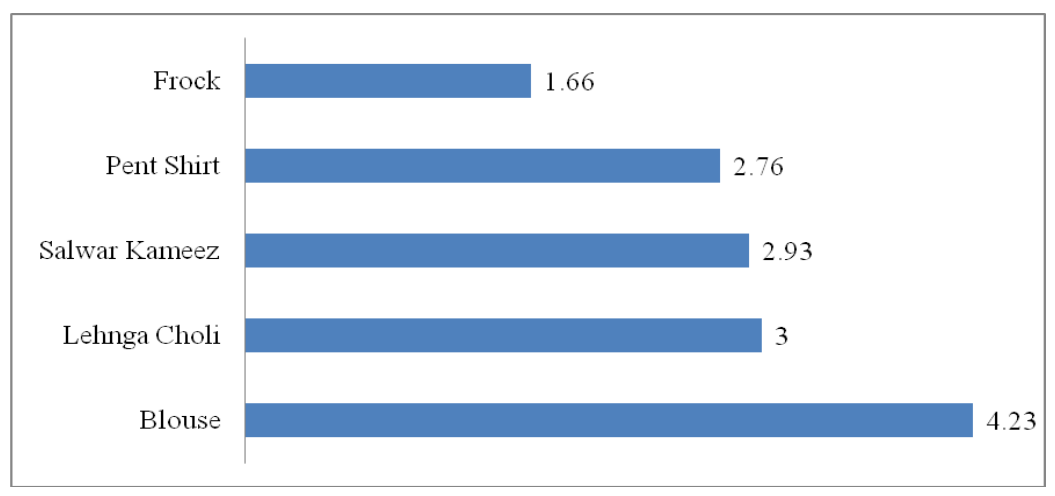

Fig.4 Distribution of products according to ratings given by respondents in Pemasar

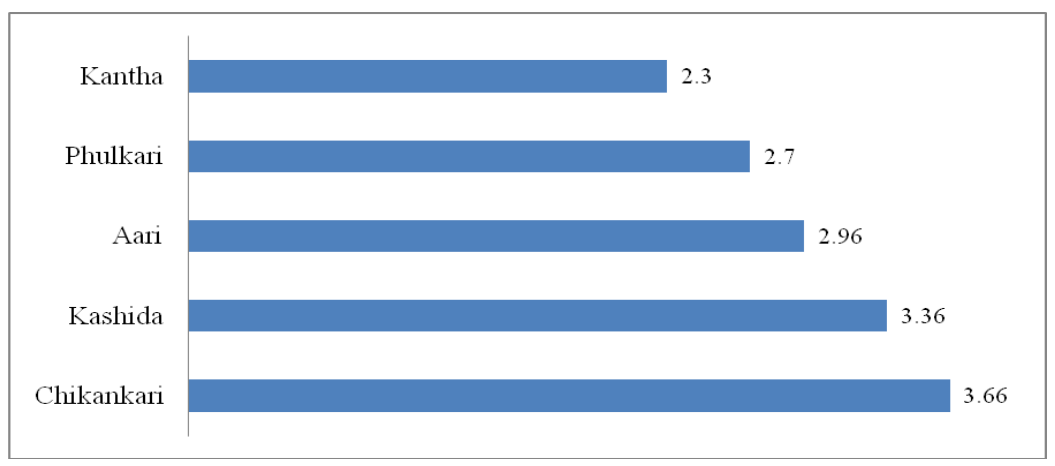

Knowledge level before training regarding stitching and embroidery in Gusaisar Village

Data in the table 10 indicates that 20 per cent respondents had low level of knowledge regarding stitching and embroidery, 70 per cent respondents had medium knowledge and 10 per cent respondents had high level of knowledge.

\section{Skill level before training regarding stitching and embroidery in Gusaisar Village}

Data in the table 11 indicates that 20 per cent respondents had low level of skill regarding stitching and embroidery, 63 per cent respondents had medium level of skill and 17 per cent respondents had high level of skill.
Knowledge level before training regarding stitching and embroidery in Seruna Village

Data in the table 12 indicates that 13 per cent respondents had low level of knowledge regarding stitching and embroidery, 67 per cent respondents had medium knowledge and 20 per cent respondents had high level of knowledge.

Skill level before training regarding stitching and embroidery in Seruna Village

Data in the table 13 indicates that 13 per cent respondents had low level of skill regarding stitching and embroidery, 70 per cent respondents had medium level of skill and 17 per cent respondents had high level of skill.

In conclusion, for the selection of product, ten products related to stitching and embroidery 
were selected on the basis of judgment of NGO trainers and interactions with field workers. The products were given to the respondents and their interest to learn the product was asked. As per the respondent's preference, the training of most preferred product was imparted to rural women. 5 point rating scale was used to identify the preference of product. After ratings of each product by respondents, average of each product's rating was computed to find the extremely interested product for training

Salwar Kameez was selected by respondents from Pemasar and Gusaisar village to learn the stitching activities in this product. Blouse was selected by respondents from Seruna Village.

Chikankari was selected by respondents from Pemasar and Seruna village to learn embroidery activities in this product. Kashidakari was selected by respondents from Gusaisar village.

For measuring the knowledge and skill of rural women, knowledge test and skill index was made. On the basis of scores, mean and standard deviation was computed and divided into three main categories. Level of knowledge and skill was analyzed on the basis of following categories:

Low

Medium

High

In Pemasar village, 33 per cent respondents had low level of knowledge regarding stitching and embroidery. 50 per cent respondents had medium knowledge and 17 per cent respondents had high level of knowledge. In Gusaisar Village, 20 per cent respondents had low level of knowledge regarding stitching and embroidery. 70 per cent respondents had medium knowledge and 10 per cent respondents had high level of knowledge. In Seruna Village, 13 per cent respondents had low level of knowledge regarding stitching and embroidery. 67 per cent respondents had medium knowledge and 20 per cent respondents had high level of knowledge (Fig. 1-4)

For measuring the skill of respondents, skill index was used. In Pemasar Village, 20 per cent respondents had low level of skill regarding stitching and embroidery. 67 per cent respondents had medium level of skill and 13 per cent respondents had high level of skill. In Gusaisar Village, 20 per cent respondents had low level of skill regarding stitching and embroidery. 63 per cent respondents had medium level of skill and 17 per cent respondents had high level of skill. In Seruna Village, 13 per cent respondents had low level of skill regarding stitching and embroidery. 70 per cent respondents had medium level of skill and 17 per cent respondents had high level of skill

\section{References}

Amudha, S., and Veerabhadriah, H., (2004), Study on identification of Major problems of Women entrepreneurs, International Journal of Marketing, 6(4), 189-190.

Asmatoddin, F., and Pawar, O., (2014), Micro, Small and Medium Enterprise Finance in India, A Research Study on Needs, Gaps and Way Forward, Sahoo Publications, 66-68.

Durkal, A. and Pandiyan, J., (2009), A critical evaluation of the contributions made by The micro, small and medium enterprises in Indian Economy, Kurukshetra, 6(5), 413-414.

Dutt, R. (1997), Enterprising women: A case study, International Journal of 
Mangement, 4(3), 105-106.

Kshtruj, H., (2009), Strategic Development of SMEs: Comparison of Policy Framework and Institutional Support Systems in India, Journal of Indian Economy, 9(4), 501.
Entrepreneurial Programmes: Lessons from examining self-efficacy, Paper presented at the 34th Institute for Small Business and Entrepreneurship Conference, New Delhi.

Kumar, B., (2006), The Impact of

\section{How to cite this article:}

Deepika Tiwari and Sharma, S. K. 2020. A Study for Entrepreneurial Knowledge of Rural Women on Stitching and Embroidery Products. Int.J.Curr.Microbiol.App.Sci. 9(10): 14321440. doi: https://doi.org/10.20546/ijcmas.2020.910.170 